\title{
ROCK STABILITY ANALYSIS ON THE MODEL OF DESIGNED AND CONSTRUCTED ROADWAYS IN THE "JAMA" BOR
}

\section{ANALIZA STABILNOSTI STENSKOG MASIVA NA MODELU PROJEKTOVANIH I IZVEDENIH PROSTORIJA U JAMI BOR}

\author{
Zlatanović Dragan ${ }^{1}$, Milisavljević Vladimir ${ }^{2}$, Tokalić Rade ${ }^{2}$, Čebašek Vladimir ${ }^{2}$
}

Received: May 14, 2015

Accepted: May 31, 2015

\begin{abstract}
For the purpose of continuous production design in the deeper levels of underground mine JAMA Bor, at first the rock stability analysis of ore deposit "Borska Reka" was performed before beginning of design the exploitation. Analysis was performed on the designed roadway model at the XVII level in ore deposit Borska Reka, with the scope of confirmation the relevance of data collected from previous research and studies. Analyses presented in this paper were performed by using software package Phase2, Rocscience Inc., which calculations are based on stress-strain condition analysis with finite element method to analyze behavior of rocks. It can be used for a wide range of engineering projects.
\end{abstract}

Key words: finite element method, rock stability, deformation

\begin{abstract}
Apstrakt: Za potrebe daljeg projektovanja eksploatacije dubljih horizonata $\mathrm{u}$ Jami Bor, a pre svega zbog početka projektovanja eksploatacije rudnog tela Borska Reka, izvršena je analiza stabilnosti stenskog masiva. Ona je rađena na modelu projektovanih prostorija na nivou XVII horizonta u rudnom telu Borska Reka, sa ciljem potvrđivanja relevantnosti podataka dobijenih na osnovu prethodnih istraživanja i studija. U radu je za analizu korišćen softverski paket Phase2, kanadske kompanije Rocscience, koji svoj rad bazira na analizi napona i deformacija uz pomoć metode konačnih elemenata za analizu stena. Može se koristiti za široki spektar inženjerskih projekata.
\end{abstract}

Ključne reči: metod konačnih elemenata, stabilnost stene, deformacije

\section{INTRODUCTION}

Development of the numerical method, especially the finite element method, opens up great opportunities to carry out rational state of stress and strain analysis of

\footnotetext{
${ }^{1}$ University of Belgrade - Faculty of Mechanical Engineering, Innovation Center, Kraljice Marije 16, 11000 Belgrade, Serbia, e-mail: dr.dragan.zlatanovic@gmail.com

${ }^{2}$ University of Belgrade - Faculty of Mining and Geology, Djušina 7, 11000 Belgrade, Serbia, e-mails: vladimir.milisavljevic@rgf.bg.ac.rs; rade.tokalic@rgf.bg.ac.rs; vladimir.cebasek@rgf.bg.ac.rs
} 
rock and soil. It can be said, that recently there has been a wider use of the finite element method for analysis the rock mass, and with this mathematical method series of very difficult problems can be solved, taking into the consideration all properties of the rock massif. Trend of common application of the Finite Element Method (FEM) in many technical disciplines should be connected with the development of computers with large scale of opportunities, which are able to solve the large scale of linear equations systems. FEM is very effective for solving problems of continuous environment mechanics. Based on the initial state of stress, it is possible to estimate stress changes and strain for the gravitational forces with usage of the load, with acceptance complex boundary conditions as well as main stress state estimate based on influence of inclined fault zone (Ljubojev et al. 2012; Ljubojev et al. 2013a).

This paper presents an approach for using the FEM for understanding problems which occurs from possible deformation of rock mass around mining works, especially roadways at the level XVII of the ore body Borska Reka in mine Jama Bor. It also shows the result of stress analysis as well as strain around underground mining works and confirmation of estimated results with existing situation.

Software package Phase2 has been used for detailed modeling and calculation, which calculations are based on analysis of stress-strain condition with finite element method to analyze behavior of rocks based on rockmass investigations for determination of failure criterion (Čebašek and Gojković, 2010).

\section{PRACTICAL APPLICATION OF FEM}

General possibilities for finite element method application as a method for the designed mining works cross-section analysis with regard to the stability analysis of the selected shape and size of the roadway is presented in this paper.

The mining works - roadways, are usually has a much pronounced one dimension (length) compared to the other two, so the problem can be considered as a two-dimensional problem.

Possible sequence of calculation is as follows:

- Technical requirements: the shape and size of the roadway, the depth;

- Characteristics of the working environment;

- $\quad$ Stress state in the rock mass;

- Determination of stress around roadway;

- Determination of stress concentration and assessment of the factor of safety.

The coefficient of stress concentration is defined as the ratio of compressive strength and tightening and stress around roadway. If is needed further analysis of the stability of the roadway, is determined by the size of the unstable zones around them (Ljubojev et al. 2013b).

\section{CASE STUDY - ANALYSIS OF ROADWAY STABILITY IN JAMA BOR MINE}

Modeling of the rock mass is done for the purpose of research the stability of underground structures. It starts from defining the geometry of underground structure 
that may lead to an increase or decrease of its stability. It is recommended that any change in the geometry follows the correct sequence. This sequence is defined by: the location of structure, its orientation, and the properties of surrounding rocks, size, fault zone and other factors.

Selection of an adequate cross-section depends on several factors, such as: the characteristics of work environment, state of stress, and dimensions or purpose of underground structure (Tokalić et al. 2013).

For this research, estimation is used on a standard cross-section of roadway which is designed and constructed at Jama Bor (4 m x $3.5 \mathrm{~m})$.

Properties of the working environment were determined like the parameters of a rock mass model in the function of strength criterion.

State of stress in ore body Borska Reka is not measured previously, therefore this information was not available. Due to the lack of knowledge of the stress state of the rock massif in the ore body Borska Reka, the stress field will be defined through gravitational component $-\gamma \mathrm{H}$. The ratio of principal stresses is assumed. Given the proximity of the ore body Tilva Ros in which the stress was measured, indicating relations between the principal stresses (Figure 1). The ratio is between $0.7 \pm 0.05$. This assessment is also accepted for ore body Borska Reka and for depth of K-155, level XVII.

It should be noted that the stress measurements were made more than twenty years ago and only on the contour of the roadway. It can be assumed that actual values are higher, if the stress was measured deeper in the rock massif.

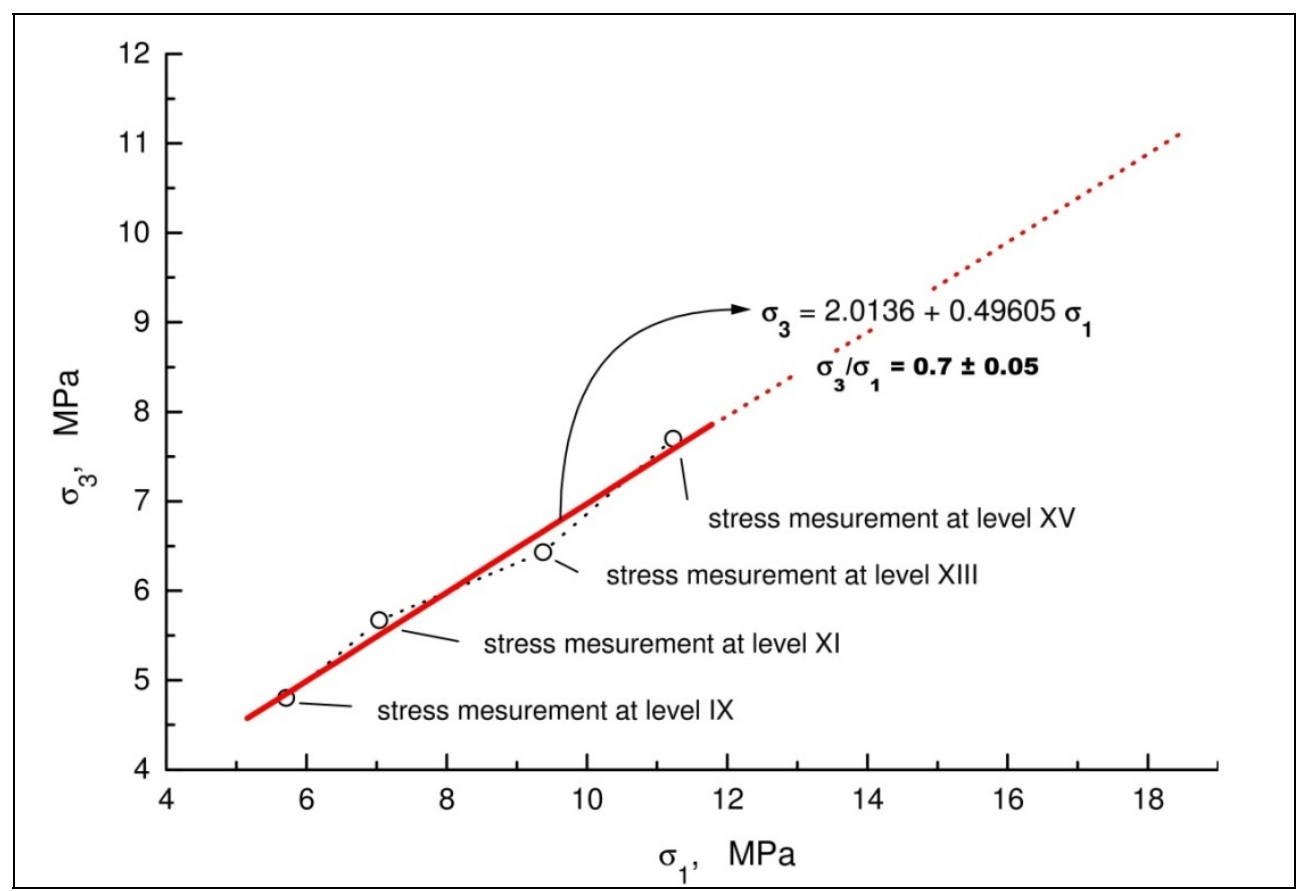

Figure 1 - Linear function of stress measured variations by depth of principal stresses for ore body Tilva Ros in mine Jama Bor 
This means that lack of the real stress values for a specific level of depth in ore body Borska Reka leads to the first obstacle in the accuracy of execution of appropriate calculations and certain conclusions. Instead of qualitative rock mass stability analysis, the empirical analysis can be performed based on estimations and assumptions in order to meet in the required range of values, but we don't have to be precisely in that required range (Zlatanović et al. 2014a; Zlatanović et al. 2014b).

Therefore, two cases are analyzed:

- $\quad$ Case 1. - The stress field is defined only by gravitational force (Model - 1) where are the main components of stress defined in ratio $1: 0.7$, and

- Case 2. - The stress field is defined by stress components $\sigma_{l}, \sigma_{3}, \sigma_{v}$ (Model - 2). Main stresses are defined so that the direction angle of the vertical stress has an angle of $45^{\circ}$ according to horizontal line with the same ratio of intensity as in the Case $1 ; \sigma_{l}$ and $\sigma_{v}$ is equal to $\gamma \mathrm{H}$, while $\sigma_{3}=0.7 \gamma \mathrm{H}$. Angle of $45^{\circ}$ also represents the average inclination angle of the ore body "Borska Reka".

Determined value of stresses taken from the Figure 1 for level XVII is for $\sigma_{1}=\sigma_{v}=14 \mathrm{MPa}$, and for $\sigma_{3}=9.5 \mathrm{MPa}$.

Boundary conditions are defined so that the stress of the model will be only under the influence of gravitational component, and the model external boundary is fixed so it cannot move in the $X$ and the $Y$ axis direction.

Both models 1 and 2 have the density of 75 points (nodes) on contour profile. With this it can be show what extent the density of the finite element affects the accuracy of the results and the interpolation accuracy, i.e. drawing the contours of stress and strain. The finite element grid is composed of triangles and is shown on each figure of results interpretation (Figures 2a, 3a).

For designed roadway cross section modeling the finite element mesh is generated with a total of 1404 elements and 729 nodes. Data entry for each model only differs in the direction of principal stresses.

As already stated, the calculations are made for two models, with stress-strain state analysis. Interpretation of results and stability assessment is given for both of defined models, which are presented in this paper.

Calculation results are interpreted with contour lines of safety factor, total displacement and principal stress. Deformation grid is also presented, deformation on model contour lines with the direction of displacement (which is magnified 100 times) as well as the plasticity zone marked with markers. Markers in the form of crosses (x) mark fracture occur due to shear stress, and in the form of circles (o) mark fracture caused by tension stress (Zlatanović, 2000).

\subsection{Model 1 - The field of stress is determined by the gravitational component $-\gamma \mathrm{H}$}

If the rock mass around a given premises located in the zone of elastic deformation, so long that zone will be stable to the apportionment factors of safety as it is shown in Figure 2b. Contour line of the safety factor of 1.3 meets the set criterion of stability. But we see that the sides of the roadway that line is farther from the contours and that consequently this area becomes susceptible to transition from elastic zones 


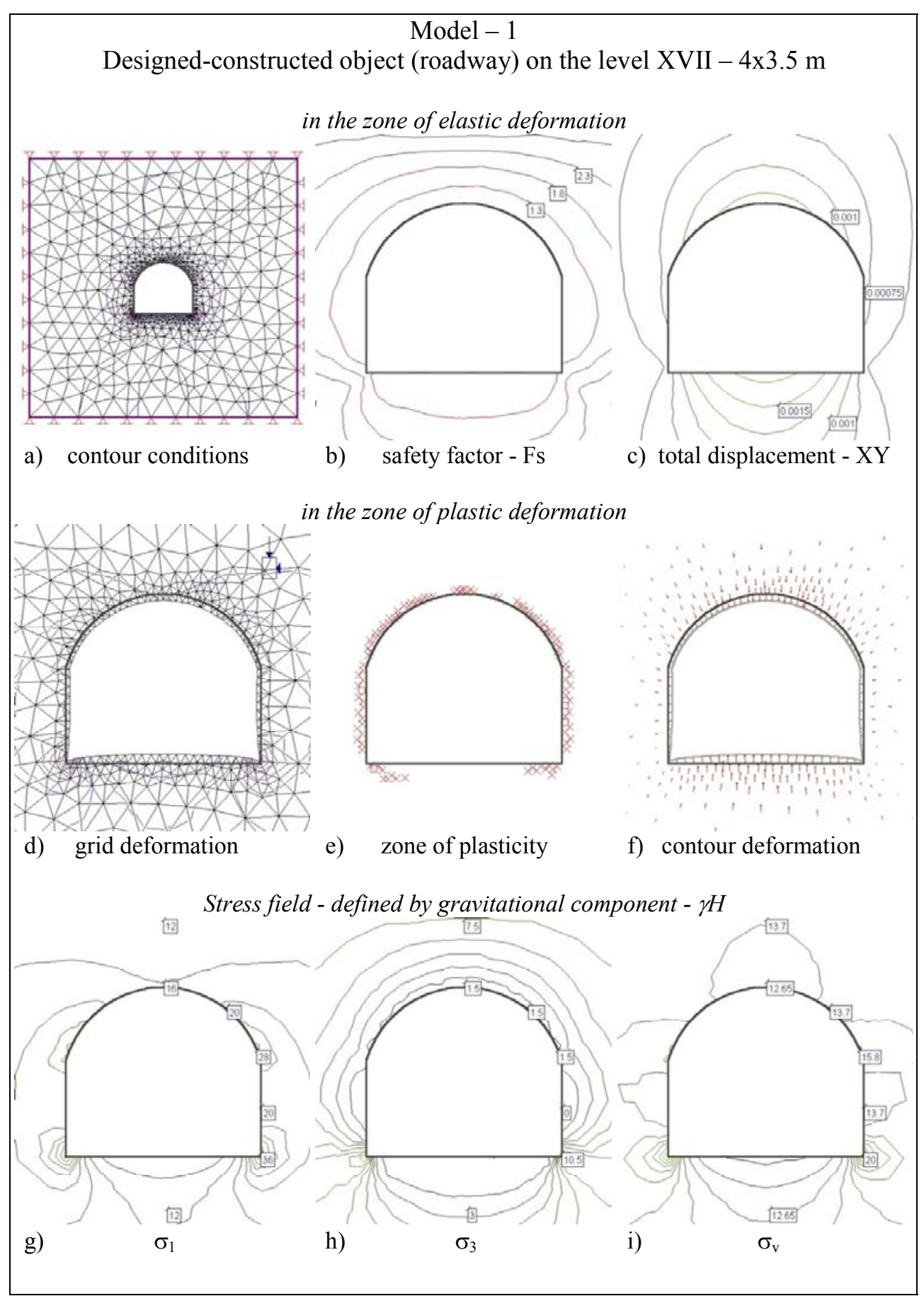

Figure 2 - Stress-strain analysis for Model 1

- in case the stress field under the influence of gravitational component $-\gamma \mathrm{H}$ 
into the zone of plastic deformation. The total displacement along the contour is $1.8 \mathrm{~mm}$ (Figure 2c).

In the parts around the roadway cross-section with plastic deformation (Figure 2e) plastic zone due to shear stress (x) will occur in the roadway arch, and complex plastic zone due to shear and tension stress ( $\mathrm{x}$ and $\mathrm{o}$ ) occurs on the sides of roadway.

One can conclude that in this case - Model 1 is stable. However, the appearance of plastic deformation, which is manifested as a sporadic rock fragmentation in the form of flaking and falling down of small pieces, could be appropriately protected with same roof support system to secure the site from future spread of damage (Milisavljević et al. 2011).

\subsection{Model 2 - The field of stress is determined by the stress components $-\sigma_{1}, \sigma_{3}$ and $\sigma_{v}$}

Principal stresses are defined so that the direction angle of the vertical stress has an angle of $45^{\circ}$ according to horizontal line and it can be seen a different distribution of stresses. As long as the contour line of the safety factor of 1.3 is closer to the cross-section in direction of principal stress, Model 2 will be stable (Figure 3b).

Plastic behavior of rock mass around the roadway does not appear evenly over the entire contour, as shown on Figure 3e, and the value of maximum displacement of $1.6 \mathrm{~mm}$.

Already here one can conclude that the change of the principal stress direction greatly changes the stress state, and therefore also influence on roadway designed shape stability factor. This highlights the importance of testing the stress state in the deeper level of the rock mass.

Based on the total displacements calculations results, one can say that these values which are not so huge that could significantly affect the stability of the observed premises. Although it doesn't mean that a given displacement should not be monitored.

Rock fragmentation is mainly induced by higher deformation. Deformation starts immediately after excavation, and it is commonly stabilized with reaction of the installed support, reaching the equilibrium of forces but it could be transform into deterioration as a result of rheological behavior of rock mass.

Rock deterioration in proximity of underground openings - roadways occurs for several reasons. Major cause is stress concentration in immediate roof and floor rocks, as well as in sides. This concentration is generated by initial equilibrium disturbance following the roadway development, resulting in concentration of vertical stress in sides of the roadway, while the horizontal stress is concentrated in the roof and the floor. Deterioration is manifested as a forming zone of deteriorated rock mass in the roadway roof. This is noted during previous research. In such zones rock is very fragmented, and deterioration zone also propagates further on into the surrounding roadway rockmass. Deterioration starts in the ribs-sides of the roadway, with increasing deterioration depth toward the roadway roof, achieving maximum depth at the roadway center line (Zlatanović et al. 2014c). 


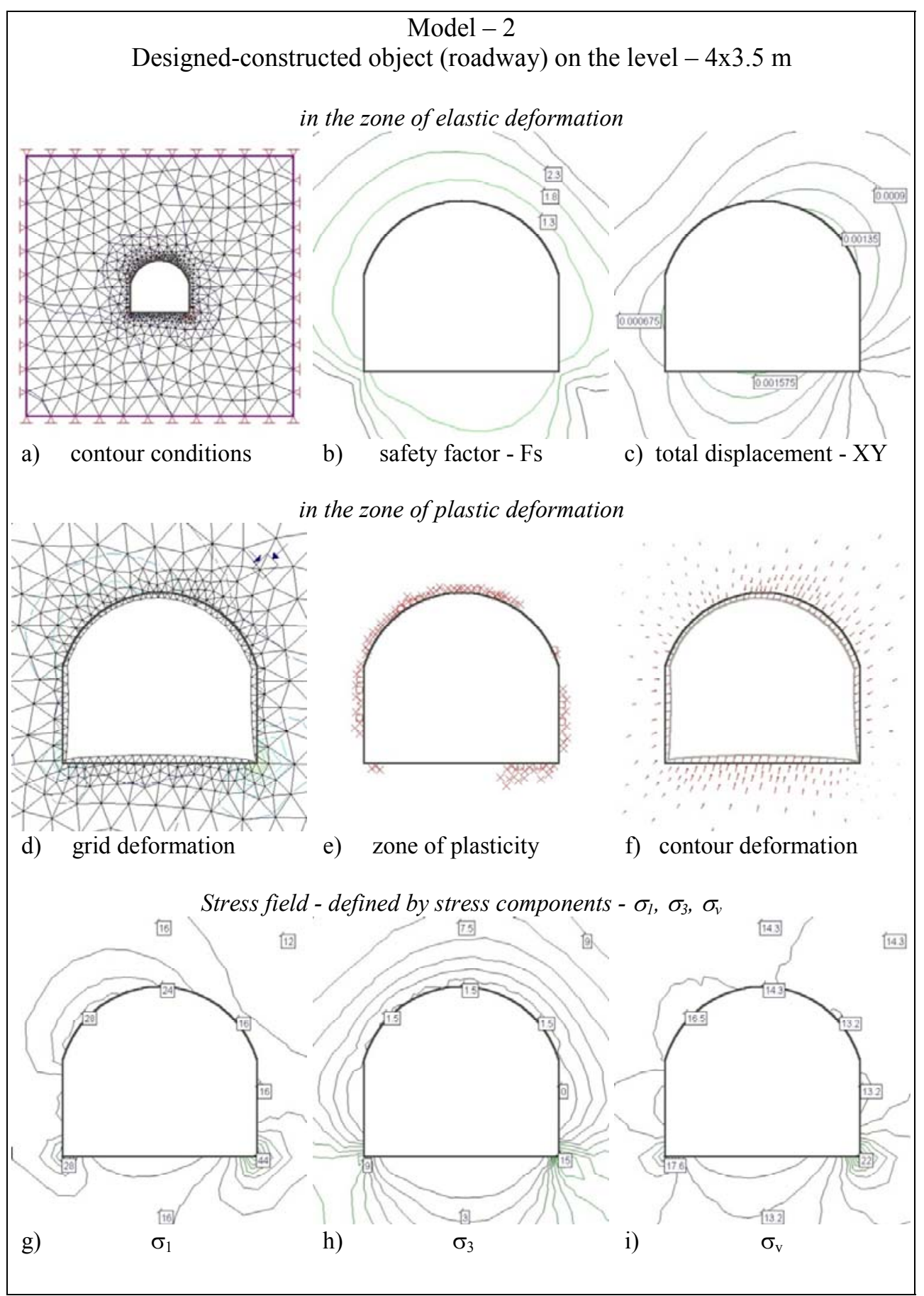

Figure 3 - Stress-strain analysis for Model 2

- in case the stress field under the influence of - $\sigma_{l}, \sigma_{3}, \sigma_{v}$ 


\section{COMPARING RESULTS OF STABILITY ANALYSIS WITH REAL STATE OF CONSTRUCTED ROADWAY ON THE LEVEL XVII}

Firstly, constructed roadway meets the conditions of stability. But if we compare selected and analyzed cross-section of Models on the level XVII with real condition of cross-section geometry of designed and constructed roadway we will get interesting results. Not because it is the actual situation for many years, but because there on some places appear partially unstable sections. In these sections there was a fracture and the appearance of the plastic zone. Partly because of a larger fault system, partly due to increased stress concentration. Here we would like to demonstrate this.

According to the stability analysis of selected models at the level XVII, stability of the selected models is generally satisfactory. First, a Model, with the correct chosen cross-section, selected for a given depth approximately $550 \mathrm{~m}$ below the ground surface and presented already constructed underground works on this level.

For the purposes of this paper, the state of the geometry of constructed roadway at the level XVII have been recording on two characteristic positions (Figure 4).

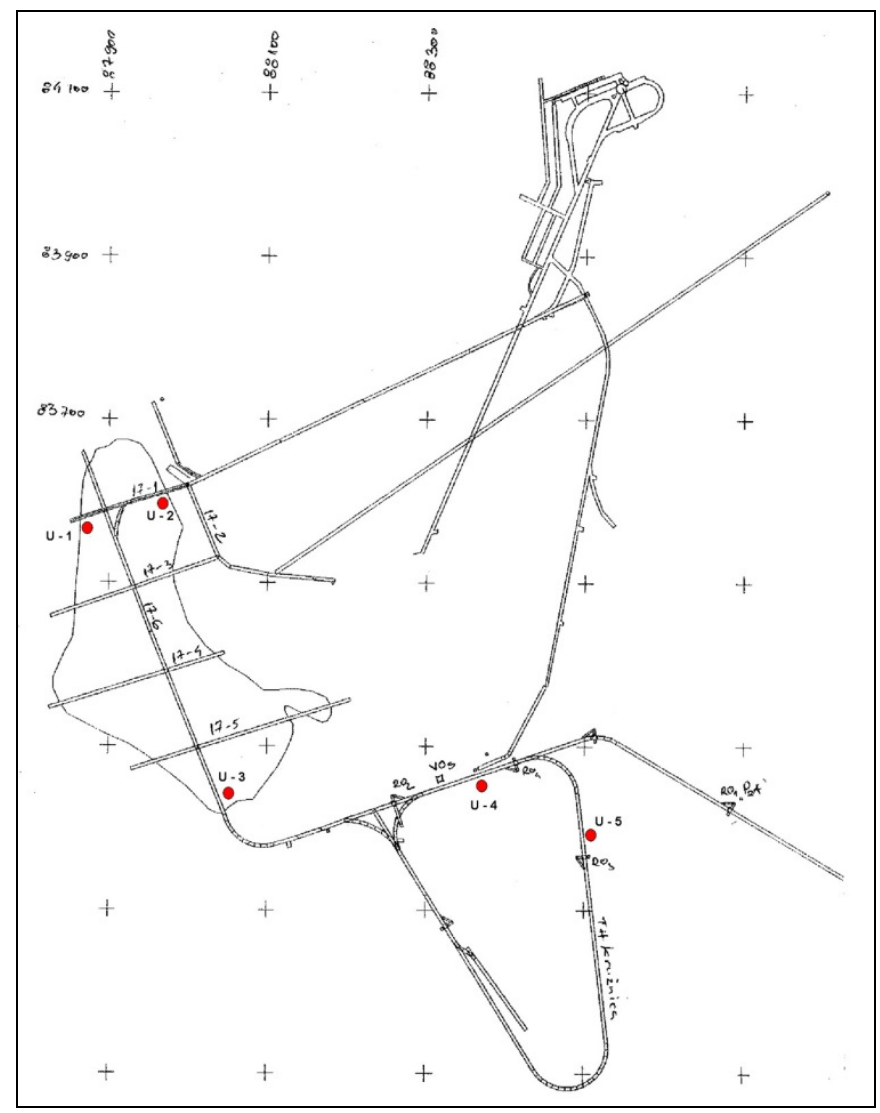

Figure 4 - Drawing roadways on the level XVII 
Geometry on the roadway 17-6 on the section between the roadway 17-3 and 17-4 (perpendicular to Bor Fault zone - Figure 5a) and geometry at the beginning of the roadway 17-1 after the curve from the roadway 17-6 (parallel to Fault zone - Figure 5) have been recorded. The dimensions of both recorded geometry was $4 \mathrm{~m} \times 3.5 \mathrm{~m}$ and match with the selected model.

One can conclude that the shape changes on roadway cross-section are around $15 \mathrm{~cm}$ to $20 \mathrm{~cm}$ higher at the positions of possible appearances of plasticity zone.

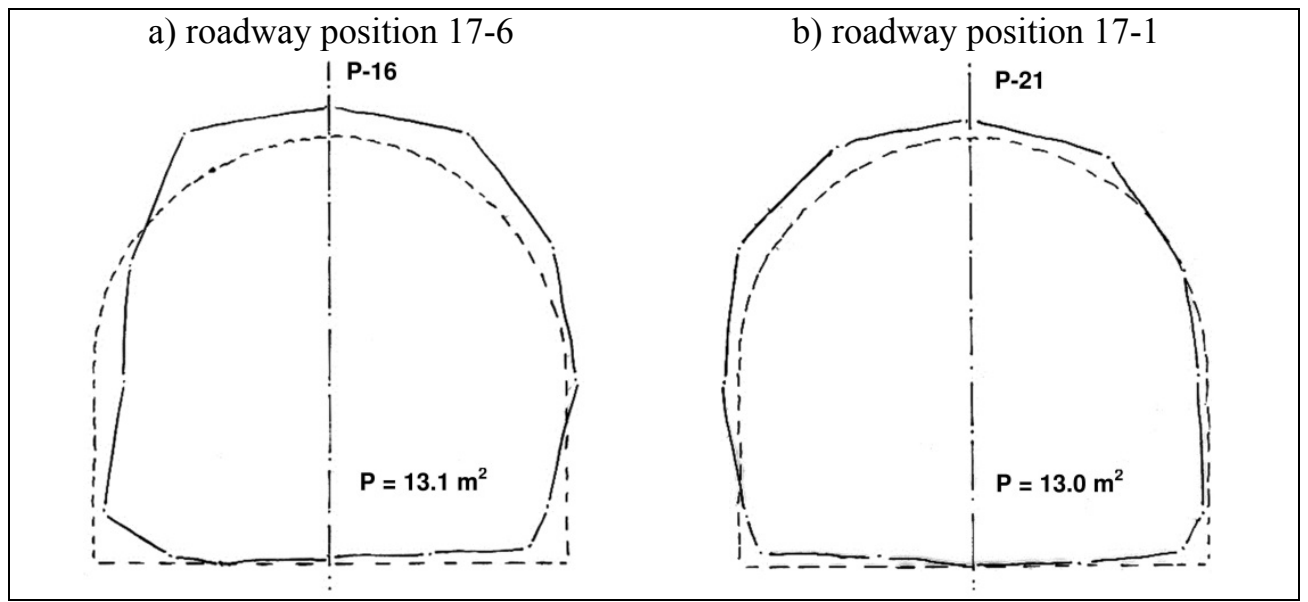

Figure 5 - State of recorded shape of roadway in relation to the design dimensions

However, if someone strictly classifies cross-section deformation (falling off small pieces from the roof and sides of the roadway) as a deformation that have been occurred under the influence of stress concentration and not under the influence of uncontrolled explosive charging or poorly oriented blast drilling holes during blasting, one can do much wrong. In any case it is necessary to monitor the behavior of the constructed profile contours, so that the causes under which change occurs can be determined with certainty.

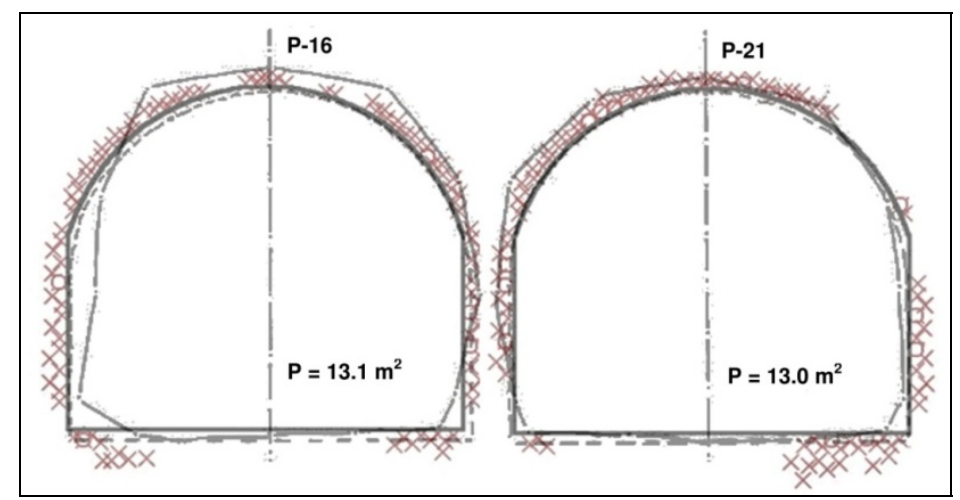

Figure 6 - Roadway condition based upon the overlap of the results of plasticity zone around contour with state of recorded shape of roadway 
A fore mentioned roadway damaged contours are, with a high probability, the result of influence of the concentration of stress and strain in the surrounding rock mass, an is best shown in Figure 6. Not only that, the parameters that are selected for the calculations, performed analysis and interpretation of results can be a good starting point for further research of behavior of the rock mass at the mine Jama Bor, especially in the ore body Borska Reka.

\section{CONCLUSION}

Development of the numerical method, especially the finite element method, with complete observation of geological, rock-mechanical and technological parameters make it possible to estimate the state of stress and strain in rock massif, interaction between rock and support, shape of underground mine working, type and thickness of supports with using program package.

This paper also present the possibility to predict the behavior of the rock mass before construction of underground facility (roadway), but it is necessary to monitor the roadway after construction and record any change.

For future design and development of mining operations it would be necessary to take into consideration results of this analysis which confirm that the shape and size of the disturbed (unstable) zone around the roadway, i.e. zones exposed to tension, with the change of direction of principal stress, changes. That is necessary to observe the possible different directions of the principal stress, taking into account the angle of inclination the ore deposit which follows the Bor fault zone.

This means that the monitoring of the changes on the contours should be performed in a corresponding time interval depending on their rate, which will allow qualitative knowledge about its nature of development. The processing of these data will allow one to correct the results of stability analysis and to improve them and apply for further prognosis of the rock mass behavior at the level on which mining operations have not been performed yet.

\section{ACKNOWLEDGEMENTS}

Research described in this paper was performed during development of the technical development projects TR33021 and TR33025. Development of those projects is funded by the Ministry of Education, Science and Technological Development of the Republic of Serbia.

\section{REFERENCES}

[1] ČEBAŠEK, V. and GOJKOVIĆ, N. (2010) Rockmass investigations for determination of failure criterion. Underground Mining Engineering, 17, pp.35-47.

[2] LJUBOJEV, M. et al. (2012): State around the mine workings. In: Proceedings of the 44th International October Conference on Mining and Metallurgy, Bor, October 2012. Bor: University of Belgrade - Technical 
Faculty in Bor, Mining and Metallurgy Institute Bor, pp.245-249.

[3] LJUBOJEV, M. et al. (2013) Probe for measuring stress-strain state in rock massif. In: Proceedings of the 45rd International October conference on Mining and Metallurgy, Bor, October 2013. Bor: University of Belgrade Technical Faculty in Bor; Mining and Metallurgy Institute Bor, pp.285-288.

[4] LJUBOJEV, M. et al. (2013) Prognosis of the zone size deformations using the finite element method on the sample of underground exploitation of the ore body "Borska Reka". In: Proceedings of the 44th International October Conference on Mining and Metallurgy, Bor, October 2013. Bor: University of Belgrade - Technical Faculty in Bor; Mining and Metallurgy Institute Bor, pp.249-252.

[5] MILISAVLJEVIĆ, V. et al. (2011) Improvement of roadway stability in Serbian underground coal mines. In: Proceedings of the 4th Balkan Mining Congress, Ljubljana, October 2011. Velenje: Velenje Coal Mine, pp.533-538.

[6] TOKALIĆ, R. et al. (2013) The rational technology model selection of the underground drivage development for the given conditions. Underground Mining Engineering, 23, pp.11-20.

[7] ZLATANOVIĆ, D. (2000) Stabilnost podzemnih objekata dubokih metaličnih ležišta na primeru rudnog tela - Borska Reka. (Magistarska teza), Rudarskogeološki fakultet, Univerzitet u Beogradu. .

[8] ZLATANOVIĆ, D. et al. (2014) Modeling of rock massif in the Jama Bor with special focus on the previous explorations of the ore body "Borska Reka". Mining \& Metallurgy Engineering, 3/2014, pp.17-32.

[9] ZLATANOVIĆ, D. et al. (2014) Determining the parameters of a rock mass model in the function of fracture criterion. In: Proceedings of the 46th International October Conference on Mining and Metallurgy, Bor, October 2014. Bor: University of Belgrade - Technical Faculty in Bor; Mining and Metallurgy Institute Bor, pp.529-532.

[10] ZLATANOVIĆ, D. et al. (2014) Results of experimental installation of roofbolting system in mines. Mining and Metallurgy Engineering, 4/2014, pp. 65-74. 